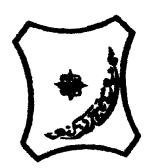

Bayero Journal of Pure and Applied Sciences, 11(2): 156 - 161

Received: May, 2018

Accepted: November, 2018

ISSN $2006-6996$

\title{
HAEMOPARASITE FAUNA OF DOMESTIC ANIMALS IN PLATEAU STATE, NORTH CENTRAL NIGERIA
}

\author{
${ }^{1}$ Ola-Fadunsin Shola David, ${ }^{2}$ Karaye Pisha Goria and ${ }^{2}$ Dogo Goni Abraham, \\ 1Department of Veterinary Parasitology and Entomology, University of Ilorin, PMB 1515, Ilorin, Kwara State, \\ Nigeria. \\ 2Department of Veterinary Parasitology and Entomology, University of Jos, Jos, PMB 2084, Plateau State, \\ Nigeria. \\ Corresponding Author: olashodam2@yahoo.com; 09060054605,
}

\begin{abstract}
Haemoparasitism remains persisting as the major challenge to animal health and production causing the destruction of red blood cells resulting in anaemia, jaundice, anorexia, emaciation, reduced productivity, infertility and even death. This study was conducted to investigate and provide information on the diversity of haemoparasites species affecting animals in Plateau State, North-central Nigeria. Blood samples collected from 1,298 apparent/y healthy animals (501 cattle; 252 sheep; 393 goats; 129 dogs and 23 horses) were parasitologically screened for the presence of haemoparasites. Babesia bigemina, Babesia bovis, Trypanosoma vivax, Anaplasma marginale, Theileria mutans and Theileria velifera were detected in cattle, with Babesia bigemina (75/501 (14.97\%); 95\% CI: 12.05 - 18.30) and Anaplasma marginale (27/501 (5.39\%); $95 \%$ CI: 3.66 7.64) been the most prevalent. Anaplasma ovis was detected in both sheep and goats, although Babesia ovis and Babesia motasi were the most prevalent blood parasites affecting sheep and goats respectively. Two species were detected each in dogs and horses with Babesia canis and Theileria equi been more prevent in dogs and horses respectively. The result of this study shows that a variety of haemoparasites species are found to infect domestic animals in Plateau State, North Central Nigeria. Considering the importance of domestic animals to national economy and the devastating effect of these haemoparasites, there is need for a radical approach in terms of appropriate and routine prophylactic treatments of animals, and regular vector (ticks and biting flies) control using efficacious acaricides and fly traps to arrest the menace.

Keywords: Blood parasites, Diversity, Plateau State, Prevalence.
\end{abstract}

\section{INTRODUCTION}

Animals that has been tamed and kept by man as a work animal, food source, means of income or pet are referred to as domestic animals. This includes a wide range of animals including cattle, sheep, goats, pigs, dogs, horses, chickens etc. Domesticated ruminants such as cattle, sheep and goats represent an important source of good quality animal protein in many developing countries of Africa including Nigeria (Unigwe et al., 2016). In Nigeria, ruminants comprising sheep, goats and cattle constitute the livestock farm animals and about 36.4 million sheep, 58.0 million goats and 16.8 million cattle are currently been reared by farm families in the country (NBS, 2016). Of the ruminant livestock, cattle are regarded as the main source of animal protein in most household, and their products such as milk, hoof, bones, blood, hides and skin are also of great economic benefits (Sam-Wobo et al., 2016).

Dogs are believed to be the first domestic animal in most parts of the world (Kamani et al., 2011). Dogs are important household pets mostly kept for various other reasons which include security purposes (personal and military), sheep herding and protection against predators, hunting and leading of the blind. In Nigeria, there has been increased interest in keeping of dogs for security and or hunting or pets and for food in some parts of the country (Okubanjo et al., 2013).

About $72 \%$ of the world's horse's population is found in the developing countries and they are kept for draft purpose in some areas (Getachew et al., 2014). Horses are been used by institutional and private owners in Nigeria for pleasure riding, polo games, ceremonies, crowd control, entertainment and research. They are associated with royalty and some special traditional festivals in the northern parts of Nigeria (Ehizibolo et al., 2012).

Haemoparasites are a heterogeneous group of organisms characterized by the presence of at least one or more developmental stages in the bloodstream of man and animals (Benedikt et al., 2009). The common blood parasites of birds and other animals are Haemoproteus species, Leucocytozoon species, Hepatozoon species, Aegyptianella species, Trypanosoma species, Plasmodium species, Babesia species, Anaplasma species, Ehrlichia (Cowdria) specie, Theileria species, Schistosoma species Leishmania species and Mycoplasma (Haemobartonella) species (Quillfeldt et al., 2011; Bhattacharjee and Sarmah, 2013; Fakhar et al., 2013; Pam et al., 2013; Opara et al., 2016). The difference in the tropical environment is the reasons suitable for 
BAJOPAS Volume 11 Number 2 December, 2018

the development of these parasitic diseases in the animals host (Ademola and Onyiche, 2013).

Haemoparasites have commonly been shown to cause destruction of red blood cells resulting in anaemia, jaundice, anorexia, emaciation, reduced productivity, infertility and even death (Ademola and Onyiche, 2013). The direct losses caused by haemoparasitism are attributed to acute illness and death, premature slaughter and rejection of some body parts at meat inspection. Indirect losses include the reduction of productive potential such as reduced birthrate, decreased milk yield, decreased growth rate, weight loss in young growing animal, late maturity of slaughter stock and decreased work efficiency of draft animals (Ademola and Onyiche, 2013; Ukwueze and Kalu, 2015). The effect of haemoparasitism in animals is determined by the interactions between the type of parasites present in the geographical area, parasite life cycles, the environment including weather patterns and type of farm management, and the host factors (Ukwueze and Kalu, 2015).

Despite several reported prevalence rates of haemoparasitic infections of domestic animals in Nigeria, infection with haemoparasites remains persisting as the major challenge to animal production due to findings from previous researchers such as Ehizibolo et al. (2012) that worked on horses in northern Nigeria, Ademola and Onyiche (2013) who worked on ruminants and pigs in Ibadan southwest Nigeria and Ukwueze and Kalu (2015) who worked on small ruminants in Umuahia southeast Nigeria.

For this reason, this present data was analysed to investigate and provide additional information on the diversity of haemoparasites species affecting animals in Plateau State, North-central Nigeria.

\section{MATERIALS AND METHODS}

\section{Study area}

This study was carried out in Jos South local government area of Plateau State, North-central Nigeria. Jos South covers an area of 5,104 square kilometers and is located between latitude 9046 to 90 $77^{\prime} \mathrm{N}$, and longitude $8^{\circ} 48$ to $8^{\circ} 80^{\prime} \mathrm{E}$. The major ethnic group is Berom beside other major settlers like Hausa, Igbo, Yoruba, Miango and Tarok etc. (Dogo et al., 2017). Plateau State covers an area of 27,147 square kilometers and is almost centrally located between latitude $80^{\circ} 24^{\prime} \mathrm{N}$ and longitude $80^{\circ} 32^{\prime}$ and $100^{\circ} 38^{\prime}$ east of the Greenwich meridian. The state has a high altitude ranging from approximately 1,200 to a peak of 1,829 metres above sea level. Plateau state has a near temperate climate with a mean annual rainfall of between $131.75 \mathrm{~cm}$ to $146 \mathrm{~cm}$ and an average annual temperature ranging from $16.3^{\circ} \mathrm{C}$ and $28.1^{\circ} \mathrm{C}$. It records a mean relative humidity of between $46.9 \%$ and $51.3 \%$ (NBS, 2016; Bolajoko et al., 2016).

\section{Blood samples and processing}

About $2 \mathrm{mls}$ of anticoagulated blood samples collected from 1,298 apparently healthy animals (501 cattle; 252 sheep; 393 goats; 129 dogs and 23 horses) in Jos south local government were submitted to the
Parasitology laboratory of the National Veterinary Research Institute Vom, for haemoparasite diagnosis. The blood samples were submitted between January and December 2012. The samples submitted were from animals raised under extensive and semiintensive management systems.

Thin blood smear was prepared using standard method as described by Cheesbrough (2000). A drop of blood was placed on one end of a clean, grease free glass slide and made into thin film with aid of a spreader (a clean glass slide). This was done by allowing the spreader to touch the blood at an angle of $45^{\circ}$, and then spread gently but firmly along the surface of the horizontal slide so that the blood is dragged behind the spreader to form the film with a feathered edge. The prepared thin film was then airdried, fixed in methanol for 5 minutes and stained in freshly prepared $10 \%$ Giemsa stain at pH $7.2(10 \mathrm{ml}$ Giemsa solution and $90 \mathrm{ml}$ buffer solution) for $25-30$ minutes. Afterwards, the stained film was rinsed in buffered water and allowed to dry. The smears were examined at X100 magnification (oil immersion) on an Olympus Microscope for the presence and identification of haemoparasites, according to Soulsby (1986) and Shah-Fischer and Say (1989).

\section{Statistical analysis}

Data was analyzed using descriptive statistics that was conducted using percentages and tabulations. The $95 \%$ confidence interval was used to determine the range in the level of prevalence of each blood parasite. All statistical tests were conducted using statistical package for social sciences (SPSS) version 22 (SPSS Inc., Chicago).

\section{RESULTS}

Of the 1,298 animal blood that were screened, cattle blood were the most numerous been 501 (38.60\%; 95\% CI: $35.98-41.27)$, followed by goat blood been 393 (30.28\%; 95\% CI: 27.82 - 32.82). Horse and dog blood were the least numerous been 23 (1.77\%; 95\% CI: 1.15 -2.61) and 129 (9.90\%; 95\% CI: $8.40-$ 11.66) respectively Table 1.

The diversity and prevalence of blood parasite species of animals in Plateau State, North Central Nigeria is presented in Table 2. Six haemoparasite species (Babesia bigemina, Babesia bovis, Trypanosoma vivax, Anaplasma marginale, Theileria mutans and Theileria velifera) were detected to infect cattle with Babesia bigemina (75/501 (14.97\%); 95\% CI: 12.05 - 18.30) and Anaplasma marginale (27/501 (5.39\%); $95 \%$ CI: 3.66 - 7.64) been the most prevalent. Babesia ovis and Anaplasma ovis were the species affecting sheep with Babesia ovis been the more prevalent haemoparasite infecting 24 of the 252 sheep screened (9.52\%; 95\% CI: $6.34-13.63)$. Of the haemoparasites (Babesia motasi and Anaplasma ovis) affecting goats, Babesia motasi was the more prevalent specie affecting 24 of the 393 goats (6.11\%; 95\% CI: 4.04 - 8.82) compared to 12 (3.05\%; 95\% CI: $1.67-5.13$ ) of Anaplasma ovis affecting the same animal. 
BAJOPAS Volume 11 Number 2 December, 2018

Two species each were detected in dogs (Babesia canis and Hepatozoon canis) and horses (Theileria equi and Babesia caballi) with Babesia canis (30/129 (23.26\%); 95\% CI: $16.57-31.13)$ and Theileria equi
(22/23 (95.65\%); 95\% CI: 80.37 - 99.78) been the more prevalent blood parasites in dogs and horses respectively.

Table 1: Demographic Information of Animals Studied for Haemoparasite Fauna in Plateau State, North Central Nigeria.

\begin{tabular}{llll}
\hline Species & Number of animals & Percentage (\%) & $95 \%$ CI \\
\hline Cattle & 501 & 38.60 & $35.98-41.27$ \\
Sheep & 252 & 19.41 & $17.33-21.63$ \\
Goats & 393 & 30.28 & $27.82-32.82$ \\
Dog & 129 & 9.94 & $8.40-11.66$ \\
Horse & 23 & 1.77 & $1.15-2.61$ \\
Total & 1298 & & \\
\hline
\end{tabular}

Table 2: Diversity and Prevalence of Haemoparasite species of Animals in Plateau State, North Central Nigeria.

\begin{tabular}{lllll}
\hline Animal (Number) & Haemoparasite specie & Number infected & Prevalence (\%) & $95 \%$ CI \\
\hline Cattle (501) & Babesia bigemina & 75 & 14.97 & $12.05-18.30$ \\
& Babesia bovis & 6 & 1.20 & $0.49-2.47$ \\
& Trypanosoma vivax & 18 & 3.59 & $2.21-5.51$ \\
& Anaplasma marginale & 27 & 5.39 & $3.66-7.64$ \\
& Theileria mutans & 6 & 1.20 & $0.49-2.47$ \\
Theileria velifera & 3 & 0.60 & $0.15-1.62$ \\
Sheep (252) & Babesia ovis & 24 & 9.52 & $6.34-13.63$ \\
& Anaplasma ovis & 15 & 5.95 & $3.50-9.42$ \\
Goats (393) & Babesia motasi & 24 & 6.11 & $4.04-8.82$ \\
& Anaplasma ovis & 12 & 3.05 & $1.67-5.13$ \\
Dogs (129) & & & & $16.57-31.13$ \\
& Babesia canis & 30 & 23.26 & $8.13-19.86$ \\
Horses (23) & Hepatozoon canis & 17 & 13.18 & $80.37-99.78$ \\
& & & & $32.13-71.70$ \\
\hline
\end{tabular}

\section{DISCUSSION}

Haemoparasite infections have been one of the most economically impactful conditions affecting human and animal health worldwide particularly in developing countries such as Nigeria at the moment (Ademola and Onyiche, 2013); hence the knowledge of its fauna, diversity and prevalence in animals is very important. Dogo et al. (2017) reported that cattle, sheep and goats are the major animal species that are been reared by people of Jos South local government area of Plateau State, North-central Nigeria. This may be the reason we had more cattle, sheep and goats samples for this study.

Six haemoparasite species (Babesia bigemina, Babesia bovis, Trypanosoma vivax, Anaplasma marginale, Theileria mutans and Theileria velifera) were detected from cattle in this study. These species with exception of Theileria velifera has been previously reported in Nigeria (Kamani et al., 2010; Ademola and Onyiche, 2013; Pam et al., 2013; Abdullahi et al., 2014) not until very recently when it was reported by Lorusso et al. (2016) who detected the parasite using molecular diagnostic technique. This shows that the parasite (Theileria velifera) may have been wrongly identified in earlier studies where basic parasitological technique was used. Although, the fact that Theileria velifera was not detected by previous researchers proves that the parasite is not endemic in Nigeria as it was the least prevalent parasite recorded in this study. Babesia bigemina and Anaplasma marginale were the most prevalent haemoparasite affecting cattle in this study. Similar to our findings, Abdullahi et al. (2014) and Zawua et al. (2015) reported Anaplasma marginale and Babesia bigemina to be the most prevalent blood parasites affecting cattle in their respective works conducted in Nasarawa and Benue states of Nigeria. Babesia bigemina and Anaplasma marginale has been reported to be the most prevalent haemoparasites affecting cattle in Gambia (Mattioli et al., 1997) and Bangladesh (Mohanta et al., 2011). The high prevalence of Babesia bigemina and Anaplasma marginale in this study maybe associated with the peculiarity of their transmission mode. Babesia bigemina transmission occurs during the nymphal and adult stages, and the tick remains infected for many generations (Dalgliesh and Stewart, 1983; OlaFadunsin, 2017). Transmission of Anaplasma marginale can occur biologically and trans-ovarially by ticks, and mechanically by biting flies, through bloodcontaminated fomites, contaminated needles, dehorning saws, nose tongs, tattooing instruments, ear tags devices and castration instruments. 
In addition, $A$. marginale may be transmitted from cow to calf trans-placentally (Ola-Fadunsin, 2017). The infection rate of between $0.60 \%$ and $14.97 \%$ of cattle haemoparasites reported in this study suggests continuous challenge by these parasites and the existence of the carrier state in the animal as well as the continuous presence of their arthropod vectors.

Babesia ovis and Babesia motasi were the more prevalent haemoparasites infecting sheep and goats respectively in this study. Although Anaplasma ovis was detected to also infect these animal species. Babesia species and Anaplasma species has been reported to be the most prevalent haemoparasites of small ruminants (sheep and goat) in northern Nigeria (Opara et al., 2016; Bello et al., 2017), southeastern Nigeria (Nwoha et al., 2013b; Ukwueze and Kalu 2015) and southwestern Nigeria (Akande et al., 2010; Sam-Wobo et al., 2016). Trypanosoma species were not detected from our study and this has been reported to be endemic among sheep and goats in southwestern Nigeria (Akande et al., 2010; Ademola and Onyiche, 2013). The non-detection of Trypanosoma species in our studies may be attributed to the fact that the sample area does not fall within the Tsetse flies infested zones of Nigeria as well as small ruminants are not natural hosts for the mechanically transmitted Trypanosoma evansi endemic to the area (Jatau et al., 2011).

Babesia canis and Hepatozoon canis were the haemoparasites detected in our study. These parasites have been reported to be the major haemoparasites of dogs in Nigeria, with the latter been more prevalent (Nwoha et al., 2013a; Opara et al., 2017) as observed in our study. Other haemoparasite species (Trypanosoma, Anaplasma, Theileria and Ehrlichia species) that were not detected in our study has been reported to affect dogs in Nigeria (Nwoha et al., 2013a; Adamu et al., 2014). The absence of these haemoparasites in our study may be attributed to the fact that the blood samples presented were for local breeds of dogs. However, Ehrlichia canis was seen in exotic breed of dog which may be attributed to breed susceptibility (Nyindo et al., 1980). Babesia canis and Hepatozoon canis has been documented to affect dogs in India (Bhattacharjee and Sarmah, 2013) and in Cape Verde (Gotsch et al., 2009). The presence of Babesia canis and Hepatozoon canis in our study may be attributed to the fact that the tick vector (Rhipicephalus sanguneus) occur in large numbers in Jos south almost all year round (Kamani et al., 2011).

Our findings show that Theileria equi (formerly Babesia equi) and Babesia caballi were the haemoparasites affecting horses in the study area. Theileria equi was almost as twice more prevalent compared to Babesia caballi. These two

\section{REFERENCES}

Abdullahi, S.M., Idris, Y., Alhaji, M.A., Kabir, I., \& Abubakar, S.M. (2014). Prevalence of haemoparasitic infections in dairy cattle (Friesian breeds) at nagari integrated dairy haemoparasites were the most prevalent reported among horses in a work carried out by Ehizibolo et al. (2012). This group of researchers reported that four species of haemoparasites infect horses in their study carried out in three states (Bauchi, Kaduna and Plateau) in northern Nigeria. The two species reported in our study may suggest that other haemoparasite species are not present among horses in the study area. The occurrence of Theileria equi and Babesia caballi has been tied closely with the geographic distribution and seasonal activity of its biological vectors (Turaki et al., 2014; Davitkov et al., 2016). Similar to our findings, higher prevalence of Theileria equi compared to Babesia caballi has been reported in horses sampled in northern Nigeria (Ehizibolo et al., 2012), northeast Nigeria (Turaki et al., 2014), in horses sampled in four widely separated states of Nigeria (Mshelia et al., 2016), outside Nigeria: in Sudan (Salim et al., 2013), Mongolia (Munkhjargal et al., 2013), central Balkan (Serbia, Montenegro and Bosnia and Herzegovina) (Davitkov et al., 2016) and Spain (Cortés et al., 2017). The higher prevalence of Theileria equi compared to Babesia caballi can be attributed to the fact that horses infected with $T$. equi may remain lifelong carriers, whereas $B$. caballi is eliminated from the bloodstream, this making the transmission and infection of the former easier and higher compared to that of the later.

\section{CONCLUSION}

Our study shows that a variety of haemoparasite species are found to infect domestic animals in Plateau State, North Central Nigeria. Haemoparasites such as Theileria equi, Babesia caballi, Babesia canis and Babesia bigemina are endemic in the area. Considering the importance of domestic animals to the nation's economy and the devastating effect of these haemoparasites, there is need for a radical approach in terms of appropriate and routine prophylactic treatments of animals, and regular vector (ticks and biting flies) control by using efficacious acaricides and fly traps to arrest the menace.

\section{Authors' contributions}

All authors participated in the overall success of this study. All authors provide substantial input, read and approved the final draft.

\section{Conflict of interest}

The authors state that there is no conflict of interest among them.

\section{Acknowledgements}

Notable thanks are due to the staff of the Parasitology laboratory of the National Veterinary Research Institute Vom, Plateau, State. Nigeria.

farms, Gauta-Nike village, Keffi local government area, Nasarawa state, north central of Nigeria. Scientific Journal of Zoology, 3(2), 17-23. 
BAJOPAS Volume 11 Number 2 December, 2018

Adamu, M., Troskie, M., Oshadu, D.O., Malatji, D.P., Penzhorn, B.L., \& Matjila, P.T. (2014). Occurrence of tick-transmitted pathogens in dogs in Jos, Plateau State, Nigeria. Parasites and Vectors, 7, 119-126.

Ademola, I.O., \& Onyiche, T.E. (2013). Haemoparasites and Haematological Parameters of Slaughtered Ruminants and Pigs at Bodija Abattoir, Ibadan, Nigeria. African Journal of Biomedical Research, 16(2), 101-105.

Akande, F.A., Takeet, M.I., \& Makanju, O.A. (2010). Haemoparasites of cattle in Abeokuta, South west Nigeria. Science World Journal, 5(4), 19-21.

Bello, A.M., Lawal, J.R., Dauda, J., Wakil, Y., Mshellia, E.S., Abubakar, M.I., \& Biu, A.A. (2017). Prevalence of haemoparasites in Balami Sheep from Maiduguri, Northeastern Nigeria. Direct Research Journal of Veterinary Medicine and Animal Science, 2(2), 28-35.

Benedikt, V., Barus, V., Capek, M., Havlicek, M., \& Literak, I. (2009). Blood parasites (Haemoproteus and microfilariae) in birds from the Caribbean slope of Costa Rica. Acta Parasitologica, 54(3), 197-204.

Bhattacharjee, K., \& Sarmah, P.C. (2013). Prevalence of haemoparasites in pet, working and stray dogs of Assam and North-East India: A hospital based study. Veterinary World, 6(11), 874-878.

Bolajoko, M., Ahmed, M.S., Okewole, P.A., Kumbish, P., Muhammad, M., \& Fyfe, J. (2016). Prevalence and Demographic Distribution of Canine Rabies In Plateau State, Nigeria, 2004 - 2009. Bulletin of Animal Health and Production in Africa, 64(1), 127-136.

Cheesbrough, M. (2000). District Laboratory Practice in Tropical Countries, Part-2. Cambridge University Press: United Kingdom.

Cortés, M.G.M., Fernández-García, J.L., \& MartínezEstéllez, M.A.H. (2017). Seroprevalence of Theileria equi and Babesia caballi in horses in Spain. Parasite, 24(14), 1-11.

Dalgliesh, R.J., \& Stewart, N.P. (1983). The use of tick transmission by Boophilus microplus to isolate pure strains of Babesia bovis, Babesia bigemina and Anaplasma marginale from cattle with mixed infections. Veterinary Parasitology, 13(4), 317-323.

Davitkov, D., Vucicevic, M., Stevanovic, J., Krstic, V., Slijepcevic, D., Glavinic, U., \& Stanimirovic, Z. (2016). Molecular detection and prevalence of Theileria equi and Babesia caballi in horses of central Balkan. Acta Parasitologica, 61(2), 337-342.

Dogo, G.I.A., Karaye, P.G., Patrobas, M.G., Galadima, M., \& Gosomji, I.J. (2017). Prevalence of Gastrointestinal Parasites and their impact in Domestic animals in Vom, Nigeria. Saudi. Journal of Medical and Pharmaceutical Sciences, 3(3), 211-216.
Ehizibolo, D.O., Kamani, J., Ehizibolo, P.O., Egwu, K.O., Dogo, G.I., \& Salami-Shinaba, J.O. (2012). Prevalence and Significance of Parasites of Horses in Some States of Northern Nigeria. Journal of Equine Science, 23(1), 1-4

Fakhar, M., Kalani, H., Rahimi-Esboei, B., \& Armat, S. (2013). Hemoprotozoa in free-ranging birds from rural areas of Mazandaran Province, northern Iran. Comparative Clinical Pathology, 22(3), 509-512.

Getachew, M., Alemayehu, F., Chala, C., Amare, B., Kassa, D., Burden, F., Wernery, R., \& Wernery, U. 2014. A cross-sectional serosurvey of some infectious diseases of working equids in central Ethiopia. Journal of Veterinary Medicine and Animal Health, 6(9), 231-238.

Gotsch, S., Leschnik, M., Duscher, G., Burgstaller, J.P., Wille-Piazzai, W., \& Joachim, A. (2009). Ticks and haemoparasites of dogs from Praia, Cape Verde. Veterinary Parasitology, 166(1\&2), 171-174.

Jatau, I.D., Abdulganiyu, A., Lawal, A.I., Okubanjo, O.O., \& Yusuf, K.H. (2011). Gastrointestinal and haemoparasitism of sheep and goats at slaughter in Kano, northern-Nigeria. Sokoto Journal of Veterinary Sciences, 9(1), 7-11.

Kamani, J., Sannusi, A., Egwu, O.K., Dogo, G.I., Tanko, T.J., Kemza, S., Tafarki, A.E., \& Gbise, D.S. (2010). Prevalence and Significance of Haemoparasitic Infections of Cattle in North- Central, Nigeria. Veterinary World, 3(10), 445-448.

Kamani, J., Weka, P.R., \& Gbise, S.D. (2011). Parasitic cause of anaemia in dogs in Vom, Nigeria. International Journal for Agro and Veterinary Medical Sciences, 5(3), 283-289.

Lorusso, V., Wijnveld, M., Majekodunmi, A.O., Dongkum, C., Fajinmi, A., Dogo, A.G., Thrusfield, M., Mugenyi, A., Vaumourin, E., Igweh, A.C., Jongejan, F., Welburn, S.C., \& Picozzi, K. (2016). Tick-borne pathogens of zoonotic and veterinary importance in Nigerian cattle. Parasites and Vectors, 9, 217-229.

Mattioli, R.C., Janneh, L., Corr, N., Faye, J.A., Pandey, V.S., \& Verhulst, A. (1997). Seasonal prevalence of ticks and tick-transmitted haemoparasites in traditionally managed N'Dama cattle with reference to strategic tick control in the Gambia. Medical and Veterinary Entomology, 11(4), 342-348.

Mohanta, U.K., Anisuzzaman, A., \& Mondal, M.M.H. (2011). Tick and Tick Borne Protozoan Diseases of Livestock in the Selected Hilly Areas of Bangladesh. International Journal of Agricultural Research, Innovation and Technology, 1(1\&2), 60-63.

Mshelia, W.P., Sambo, K.W., Adamu, S., Edeh, E.R., \& Onoja, I.I. (2016). Persistence of equine piroplasmosis in horses in Nigeria. 10th 
BAJOPAS Volume 11 Number 2 December, 2018 IEIDC Abstracts / Journal of Equine Veterinary Sciences, 39, S982-S1107.

Munkhjargal, T., Sivakumar, T., Battsetseg, B., Nyamjargal, T., Aboulaila, M., Purevtseren, B., Bayarsaikhan, D., Byambaa, B., Terkawi, M.A., Yokoyama, N., \& Igarashi, I. (2013). Prevalence and genetic diversity of equine piroplasms in Tov province, Mongolia. Infection, Genetics and Evolution, 16, 178185.

National Bureau of Statistics (NBS) 2016. Annual Abstract of Statistics. Federal Republic of Nigeria.

Nwoha, R.I.O., Daniel-Igwe, G., Onuekwusi, G.C., Onyeabor, A., Igwe, K.C., \& Okah, U. (2013a). Incidences of Haemoparasites in Dogs in Ikwuano Local Government Area of Abia State. Journal of Veterinary Science and Technology, 4(4), 42-6.

Nwoha, R.I.O., Onyeabor, A., Igwe, K.C., DanielIgwe, G., Onuekwusi, G.C.O., \& Okah, U. (2013b). Prevalence of Haemoparasites in Livestock in Ikwuano Local Government Area of Abia State. Journal of Fisheries and Livestock Production, 2(1), 1092-1111.

Nyindo, M., Huxsoll, D.L., Ristic, M., Kakoma, I., Brown, J.L., Carson, C.A., \& Stephenson, E.H. (1980). Cell-mediated and humoral immune responses of German Shepherd Dogs and Beagles to experimental infection with Ehrlichia canis. American Journal Veterinary Research, 41(2), 250-254.

Okubanjo, O.O., Adeshina, O.A., Jatau, I.D., \& Natala, A.J. (2013). Prevalence of Babesia canis and Hepatozoon canis in Zaria, Nigeria. Sokoto Journal of Veterinary Sciences, 11(2), 15-20.

Ola-Fadunsin, S.D. (2017). The diversity and epidemiology of bovine haemoparasites and their potential arthropod vectors in Peninsular Malaysia. Ph.D Thesis: Universiti Putra Malaysia.

Opara, M.N., Adewumi, T.S., Mohammed, B.R., Obeta, S.S., Simon, M.K., Jegede, O.C., \& Agbede, R.I.S. (2017). Investigations on the Haemoprotozoan Parasites of Nigerian Local Breed of Dogs in Gwagwalada Federal Capital Territory (FCT) Nigeria. Research Journal of Parasitology, 12(1), 1-7.

Opara, M.N., Santali, A., Mohammed, B.R., \& Jegede, O.C. (2016). Prevalence of Haemoparasites of Small Ruminants in Lafia Nassarawa State:
A Guinea Savannah Zone of Nigeria. Journal of Veterinary Advances, 6(6), 1251-1257.

Pam, V.A., Ogbu, K.I., Igeh, C.P., Bot, C.J., \& Vincent, G. (2013). Prevalence of Endoparasites of Horses in Jos North and Jos South Local Government Areas of Plateau State Nigeria. Journal of Animal Science Advances, 3(2), 103-108.

Quillfeldt, P., Arriero, E., Martínez, J., Masello, J.F., \& Merino, S. (2011). Prevalence of blood parasites in seabirds - a review. Frontiers in Zoology, 8(26), 26-35.

Salim, B., Bakheit, M.A., Kamau, J., \& Sugimoto, C. (2013). Current status of equine piroplasmosis in the Sudan. Infection, Genetics and Evolution, 16, 191-199.

Sam-Wobo, S.O., Uyigue, J., Surakat, O.A., Adekunle, N.O., \& Mogaji, H.O. (2016). Babesiosis and other Heamoparasitic Disease in a Cattle Slaughtering Abattoir in Abeokuta, Nigeria. International Journal of Tropical. Disease \& Health, 18(2), 1-5.

Shah-Fischer, M., \& Say, R.R. (1989). Manual of Tropical Veterinary Parasitology. CAB International, Wallingford Oxon: Ox $108 \mathrm{D}$ E, UK.

Soulsby, E.J.L. (1986). Helminths, Arthropods and Protozoa of Domestic Animals (7th Edition). Beilliere Tindall, London: Philadelphia and Toronto.

Turaki, U.A., Kumsha, H.A., Biu, A.A., \& Bokko, P.B. (2014). Prevalence of Piroplasmosis amongst local horses in Northeastern Nigeria. IOSR Journal of Agriculture and Veterinary Science, 7(12), 4-7.

Ukwueze, C.S., \& Kalu, E. (2015). Prevalence of Haemoparasites in Red Sokoto Goats Slaughtered at Ahiaeke Market, Umuahia, Abia State, Nigeria. Journal of Veterinary Advances, 5(2), 826-830.

Unigwe, C.R., Ogbu, U.M., Balogun, F.A., Orakwue, O.K., Nwufoh, O.C., \& Nwachukwu, B.C. (2016). Prevalence of Small Ruminant Diseases/Disorders at Mokola Veterinary Hospital, Ibadan, Nigeria. Journal of Biology, Agriculture and Healthcare, 6(1), 107-112.

Zawua, T.P., Amali, E.U., Amuta, O., \& Sar, T.T. 2015. Haemoparasites of cattle slaughtered for sale within Gboko Metropolis of Benue State, Nigeria. Nigerian Journal of Parasitology, 36(1), 72-76. 